\title{
Influence of lime, zinc and boron on soybean yield and nutrient availability in lateritic soil of Konkan
}

P.K. RATHOD, V.G. SALVI, S.S. PAWAR AND K.N. CHAVAN

Received : 18.09.2016; Revised : 30.10.2016; Accepted : 23.11.2016

MEMBERS OF RESEARCH FORUM:

Corresponding author :

P.K. RATHOD, Department of Soil Science and Agricultural Chemistry, College of Agriculture, (Dr.BSKKV)

Dapoli, RATNAGIRI (M.S.) INDIA
Co-authors :

V.G. SALVI, S.S. PAWAR AND K.N. CHAVAN, Department of Soil Science and Agricultural Chemistry, College of Agriculture, (Dr.BSKKV) Dapoli, RATNAGIRI (M.S.) INDIA

\section{Summary}

A field experiment was conducted during Kharif on lateritic soil of Botany Farm, College of Agriculture, Dapoli in Konkan region of Maharashtra to study the effect of lime, zinc and boron on soybean yield and available nutrients in soil during crop growth. The experiment was laidout in Randomized Block Design with three replications. The treatments consisting two levels of liming i.e. $1 / 2 \mathrm{LR}$ and $1 \mathrm{LR}$ in combination with soil and foliar application of $\mathrm{Zn}$ and $\mathrm{B}$ in their combinations. The results of the experiment showed significantly increased the grain $\left(25.52 \mathrm{q} \mathrm{ha}^{-1}\right)$ and straw $\left(37.29 \mathrm{q} \mathrm{ha}^{-1}\right)$ yield of soybean due to application of $1 \mathrm{LR}+\mathrm{Zn}+\mathrm{B}$ through soil and foliar spray along with RDF. The available major as well as secondary nutrients at grand growth period and at harvest of soybean significantly recorded highest values of available $\mathrm{N}, \mathrm{P}_{2} \mathrm{O}_{5}, \mathrm{~K}_{2} \mathrm{O}$ and $\mathrm{S}$ exchangeable $\mathrm{Ca}$ and $\mathrm{Mg}$ and available $\mathrm{S}$ with treatment $\mathrm{RDF}+1 \mathrm{LR}+\mathrm{Zn}$ and $\mathrm{B}$ through soil and foliar spray, closely followed by application RDF +1 $\mathrm{LR}+\mathrm{B}$ through soil and foliar spray.

Key words : Lime, Zinc, Boron, Soybean, Yield, Available major, Secondary nutrients

How to cite this article : Rathod, P.K., Salvi, V.G., Pawar, S.S. and Chavan, K.N.(2016). Influence of lime, zinc and boron on soybean yield and nutrient availability in lateritic soil of Konkan. Asian J. Soil Sci., 11 (2) : 341-347 : DOI : 10.15740/HAS/AJSS/11.2/341-347. 